\title{
Targowica, czyli obrona Rzeczypospolitej
}

Jarosław Porazinski

TEKSTY DRUGIE 2021, NR 3, S. 67-83

DOI: $10.18318 /$ td.2021.3.5

$\mathbf{T}$

Targowica" funkcjonuje jako synonim i symbol zdrady narodowej co najmniej od 1792 roku, a więc od chwili, gdy grupa polskich magnatów i dygnitarzy kierowanych przez „hultajską trójkę"” (generała artylerii koronnej Szczęsnego Potockiego, hetmana wielkiego koronnego Franciszka Ksawerego Branickiego i hetmana polnego koronnego Seweryna Rzewuskiego²), niezadowolonych z przyjętych w Konstytucji 3 maja 1791 rozwiązań ustrojowych, zwróciła się do carycy Katarzyny $\mathrm{II}^{3} \mathrm{z}$ prośbą o interwencję i pomoc w wydobyciu się spod

1 To określenie K. Zbyszewskiego Niemcewicz od przodu i tyłu, Gebethner i Ska, Warszawa 1991, s. 228. Pod aktem z 14 maja 1792 roku znalazły się w sumie podpisy 12 osób.

2 "No, ten to chyba z nami nie pójdzie...", miała podobno powiedzieć Katarzyna II na wieść o zmianie orientacji przez tego "upiora konfederacji barskiej"; S. Cat-Mackiewicz Stanisław August, Universitas, Kraków 2012, s. 337.

3 O rozmowach w Petersburgu i ich atmosferze por. np. J. Łojek Geneza i obalenie Konstytucji 3 maja. Polityka zagraniczna Rzeczypospolitej 1787-1792, Wydawnictwo Lubelskie, Lublin 1986, s. 260 i nast.

Jarosław Porazinski

- prof. dr hab., emerytowany pracownik Instytutu Historii i Archiwistyki UMK w Toruniu. Zajmuje się historią nowożytną Polski (XVI-XVIII w.).

Przedmiotem jego badań są problemy związane z historią ustroju, parlamentaryzmu staropolskiego, kultury politycznej. Szczególnym obszarem zainteresowania jest epoka saska (1697-1763). Kontakt: porazinski@poczta. onet.pl 
hańbiącego „jarzma” nowych praw, o przywrócenie dawnego rządu wolnego, a koniec końców o „oddanie Polski Polakom”4. To oznaczało rzeczywiście zdradę stanu, ale nie wszyscy formułowali oskarżenia w tak kategoryczny sposób, starając się zrozumieć racje i intencje targowiczan, tym bardziej że wśród ojców tego ruchu znaleźli się najważniejsi dygnitarze i urzędnicy państwa. Byli to często ludzie o szerokich horyzontach. Tadeusz Kościuszko, przebywający w 1792 roku na emigracji w Lipsku, przestrzegał przed formułowaniem jednoznacznych opinii o targowiczanach: „[...] ja pytam kto sumiennie powiedzieć może, że na ich połączenie i skojarzenie [owej "hultajskiej trójki” - przyp. moje J.P.] nie wpływało także przekonanie, że szczęście i byt Polski polega na rządzie republikańskim?"'. Bo też istotnie, akt konfederacji wyrażał sprzeciw wobec zamachu stanu i „rewolucji” 3 maja ${ }^{6}$. W rezultacie tego zamachu (rewolucji) wbrew prawu obalono „republikę" i wprowadzono „monarchię". Zdrajcami, którzy nadużyli władzy i zaufania, byli więc autorzy owych wydarzeń oraz król, bo on nowe prawo zaprzysiągł. Ale nie te racje były decydujące. Jak to ujęła Katarzyna II: „zdrowsza część narodu [...] skonfederowała się dla odzyskania praw, które jej wydarte zostały. Przyrzekłam jej pomoc i będę się starała uczynić ją skuteczną, o ile mi środki dozwolą"7. Słowa dotrzymała.

Richard Butterwick, w monumentalnej pracy o roli Kościoła katolickiego w wydarzeniach z lat 1788-1792 przyjął określenie „rewolucja”,

4 Literatura na temat konfederacji targowickiej jest spora - dość wymienić: W. Smoleński Konfederacja targowicka, Wydawnictwo Kurpisz s.a., Kraków 1903; J. Wąsicki Konfederacja targowicka i ostatni sejm Rzeczypospolitej z 1793 r. Studium historyczno-prawne, Poznańskie Towarzystwo Przyjaciół Nauk, Poznań 1952; W. Łukaszewicz Targowica i powstanie kościuszkowskie. Zestudiów nad historią Polski w XVIII wieku, Wydawnictwo MON, Warszawa 1953; E. Rostworowski Ostatni król Rzeczypospolitej. Geneza i upadek Konstytucji 3 maja, Wydawnictwo Wiedza Powszechna, Warszawa 1966; J. Łojek Dzieje zdrajcy. Szczęsny Potocki, Wydawnictwo Alfa, Warszawa 1995 i in.; por. też nadal częściowo aktualne uwagi Ł. Kądzieli O potrzebie badań nad dziejami Targowicy, "Przegląd Historyczny" 1989 t. $80 \mathrm{nr} 2$.

5 Cyt. za: J. Tazbir Próby zrozumienia racji targowiczan, w: Trudne stulecia. Studia z dziejów XVII i XVIII wieku ofiarowane Profesorowi Jerzemu Michalskiemu w siedemdziesiątą rocznicę urodzin, red. Ł. Kądziela, W. Kriegseisen, Z. Zielińska, Wydawnictwo Semper, Warszawa 1994, s. 235-236. W. Stanek Konfederacje generalne koronne wXVIII wieku, Wydawnictwo Adam Marszałek, Toruń 1991 , s. 225. rozbiorów 1772-1799. Studya do historii ducha i obyczaju J.I. Kraszewskiego, t. 3 1791-1799, Nakład Gebethnera i Wolfa Warszawa 1903, s. 213. 
przypominając, że pojęciem „łagodna rewolucja” posłużył się już Hugo Kołłątaj ${ }^{8}$. Ale ważny pozostawał również kontekst, w jakim tego pojęcia używano. W latach 9o. XVIII wieku bowiem „rewolucja” miała fatalne konotacje, co związane było z wydarzeniami we Francji. Narastał lęk przed jakobinizmem i radykalizacją społeczeństwa. Wydarzenia w Polsce biegły przecież niemal równolegle do wydarzeń we Francji. Między innymi z tego powodu Stanisławowi Augustowi zależało na tym, żeby Konstytucję 3 maja poparł papież - chodziło o podkreślenie różnicy między rewolucją polską i francuską․ Rewolucja polska miała być łagodna, bo nie stosowano w niej terroru, nie niszczono Kościoła i nie prześladowano duchowieństwa katolickiego. Ale wszelki opór wobec rewolucji, nawet „łagodnej”, nietrudno było uzasadnić. Ideowe podstawy sojuszu Rosji, Prus i Austrii były jasne - mocarstwa podejmowały walkę z "polską rewolucją", bo dostrzegały w niej wpływy... jakobińskie. Ów mniemany jakobinizm stanowić miał też zagrożenie dla innych państw europejskich.

Targowiczanie, zapewne mimowolnie, wpisywali się w ten antyrewolucyjny i antyjakobiński nurt ${ }^{10}$, ale ich postępowanie zostało uznane w Polsce za zdradę. Timothy Garton Ash w jednym ze swoich wykładów zwrócił uwagę na ciekawą paralelę między wydarzeniami w Polsce w 1792 roku i w Anglii w 1689. Chodziło o tzw. chwalebną rewolucję, która dała podstawę mitu założycielskiego demokracji angielskiej. Otóż - twierdzi Ash - w istocie w Anglii wydarzyła się... „Targowica, ponieważ grupa arystokratów brytyjskich obaliła króla z obcą pomocą. Wilhelm Orański [...] najechał Anglię swoim wojskiem. Wojna rozegrała się w Szkocji i w Irlandii, gdzie doszło do rozbiorów [...]

8 Zwrócił na to uwagę B. Leśnodorski „Łagodna rewolucja” w starciu z despotyzmem , "Czasopismo Prawno-Historyczne" 1975 t. 27, s. 187 i nast. Problemem zajął się gruntownie W. Szczygielski Sejm Wielki (1788-1792). Studium z dziejów łagodnej rewolucji, Łódzkie Towarzystwo Naukowe, Łódź 2015; por. też recenzję tej pracy pióra A. Stroynowskiego "Przegląd Nauk Historycznych" 2017 t. 16 nr 1; R. Butterwick Polska rewolucja a Kościół katolicki 1788-1792, przeł. M. Ugniewski, Kraków 2019, Wydawnictwo Arcana, s. 25 i in. Warto przypomnieć, że Kołłątaj przywołuje opinię Kazimierza Sapiehy z 13 X 1789 r. "nasz sejm jest rewolucją, ale rozsądną, bo złe ustawy obalił, i zrzucił obcą przemoc" (O ustanowieniu i upadku Konstytucyi Polskiej 3 maja 1791 przez Księdza Hugona Kołłątaja, t. VI, Paryż br., s. 33). Kołłątaj w swoim dziele określał konfederację targowicką jako rokosz. społecznym, por. R. Lis Od pochwały "demokracji szlacheckiej” do krytyki „rzqdu monarchiczno-demokratycznego". Konfederacja targowicka a tendencje rozwojowe szlacheckiego republikanizmu, „Politeja” $2018 \mathrm{nr} 4$ (55), s. 43-55. 
Z Targowicy, najazdu, wojny i rozbiorów Anglicy ułożyli piękny założycielski mit naszej (tzn. angielskiej - przyp. J.P.) demokracji"11.

Ale mit ten, mówił dalej Ash, stworzył brytyjski historyk Thomas Babington Macaulay dopiero po 160 latach od wydarzenia...

Zdradę targowiczan nie tylko zdefiniowano ad hoc, ale też uczestniczących w niej „aktorów” surowo ukarano ${ }^{12}$, co zresztą nie było do końca zgodne z tradycjami Rzeczypospolitej, w której zdrajcom zwykle wybaczano, oczywiście po publicznie wyrażonej skrusze i przeprosinach. Dość wspomnieć XVII-wiecznych zdrajców - Hieronima Radziejowskiego ${ }^{13}$ i Jerzego Sebastiana Lubomirskiego ${ }^{14}$. Oba te przypadki zdrady opinia szlachecka łączyła zresztą ze sobą, dzieląc się na zwolenników i przeciwników kary. Na sejmie 1665 roku jeden z posłów, zwolennik Lubomirskiego, mówił: „[...] zdrajców większych, jako to pana Radziejowskiego, potkała restytucya, a tego civem, z przodków swych i ex meritis suis zasłużonego i godniejszego, potkać by nie miała - przyszłoby i sejmowi nie być sejmem"15. To rzeczywiście interesujący przykład relatywizmu zdrady politycznej, a może też zarazem jej swoista presocjologia.

W początkach panowania Augusta II pamięć o Hieronimie Radziejowskim powróciła. Jego syn Michał, kardynał i prymas Polski, jako przywódca opozycji antykrólewskiej został publicznie upokorzony przez zwolenników króla na sejmie w 1703 roku, którzy wypominali mu, iż jest synem zdrajcy, a zatem sam jest do zdrady skłonny ${ }^{16}$. Zwróćmy uwagę, że ci „wielcy” zdrajcy byli ważskiego, wykład wygłoszony 3 czerwca 2019 w Fundacji im. Stefana Batorego; https://oko.press/ timothy-garton-ash-zmarnowana-rewolucja-1989-polacy-czy-naprawde-zyc-umieciedopiero-w-klesce/.

Por. interesujące rozważania A. Haskiej Hańba. Opowieści o polskiej zdradzie, W.A.B., Warszawa 2018, s. 10 i nast.

A. Kersten Hieronim Radziejowski. Studium władzy i opozycji, PIW, Warszawa 1998.

Por. np. S. Płaza Rokosz Lubomirskiego, Krajowa Agencja Wydawnicza, Kraków 1994; M. Nagielski Rokosz Jerzego Lubomirskiego w 1665 roku, Wydawnictwo Neriton, Warszawa 1994; w kontekście naszych rozważań należy zwrócić tu uwagę na działania komunikacyjne obozu królewskiego Jana Kazimierza, które zapowiadały „pojawienie się propagandy prasowej i public relations" - por. M. Nieć Komunikowanie polityczne w społeczeństwach przedmasowych, Wydawnictwo Wolters Kluwer, Warszawa 2011, s. 207 i in.

A. Kersten Hieronim Radziejowski, s. 561.

K. Jarochowski Dzieje panowania Augusta II od wstąpienia na ziemię polskq aż do elekcji Stanisława Leszczyńskego (1702-1704), Nakładem i czcionkami Ludwika Merzbacha, Poznań 1864, 
nymi urzędnikami i dygnitarzami. Ich status pozostawał tak znaczący, że nikt nie miał odwagi podjąć decyzji o surowej karze. Takie sprawy rozstrzygane były zresztą podczas sądów sejmowych, gdzie zawsze decydowały względy polityczne i siła stronnictw. Skromnie wyglądał też dorobek ustawodawczy w zakresie kar za zbrodnię zdrady stanu.

Dopiero w dobie Sejmu Wielkiego, aby zabezpieczyć jego zdobycze, wprowadzono surowe zapisy przewidujące kary za czyny wymierzone „przeciwko najwyższemu Rzeczypospolitej rządowi", konfederacje zaś uznawano za spiski ${ }^{17}$. Zgodnie z tą wykładnią Kołłątaj traktował targowicę jako rokosz. O próbie zinstytucjonalizowanej lustracji i rozliczenia zdrajców w okresie powstania kościuszkowskiego już wspominałem, ale warto do tego wątku powrócić. Otóż w przypadku ludzi targowicy konsekwencje wyciągnięto rzeczywiście bez zwłoki. Nie tylko zostali oni współcześnie napiętnowani i upokorzeni publicznie, ale też niektórych powieszono podczas insurekcji warszawskiej w 1794 roku lub symbolicznie - in effigie ${ }^{18}$. Wcześniej, a więc po ostatnim sejmie Rzeczypospolitej w Grodnie w 1793 roku, na którym posłowie i senatorowie zaakceptowali drugi rozbiór, także jego liderzy polityczni (nie wszyscy byli zresztą targowiczanami) zostali uznani za zdrajców. Janusz Tazbir zauważył słusznie, że to właśnie sejm 1793 roku był momentem zwrotnym zarówno w kwalifikacji prawnej czynu, jak też w kształtowaniu się oceny targowicy. To były ostatnie chwile Rzeczypospolitej. Targowiczanie wykonali swoje zadanie tak, jak tego chciała Rosja, czyli spacyfikowali kraj ${ }^{19}$ - i mogli odejść. Nie wolno im było zgodzić się na kolejny rozbiór, bo byłoby to sprzeczne z aktem założycielskim związku. Wszystko odbywało się w majestacie prawa, co stanowiło zresztą problem przede wszystkim Rosji, troskliwie dbającej o przestrzeganie polskiego prawa. Brzmi to może paradoksalnie, ale jest zrozumiałe ze względu na jej główny cel - przeprowadzenie

s. 320-324; J. Porazinski Sejm lubelski w 1703 roku i jego miejsce w konfliktach wewnętrznych na początkuXVIII wieku, PWN, Warszawa-Poznań-Toruń 1988, s. 74 i nast.

17 Por. Z. Kaczmarczyk B. Leśnodorski Historia państwa i prawa Polski. Tom Il od połowy XV wieku do r. 1795, red. J. Bardach, PWN, Warszawa 1966, s. 333 i 573-574. Nowe prawo o sądach sejmowych dawało tym sądom kompetencje w zakresie sądzenia zbrodni przeciwko narodowi i przeciwko rządowi, czyli władzy ustawodawczej i wykonawczej. Najwyższy wymiar kary - śmierć i wieczną infamię - przewidywano dla "hersztów". Ale nie było tam definicji tych pojęć.

18 W nietypowy sposób przedstawił ten problem w swoim głośnym eseju historycznym Jarosław Marek Rymkiewicz; zob. tegoż Wieszanie, Warszawa 2007. 
kolejnego rozbioru w taki sposób, aby został możliwie powszechnie zaakceptowany. Targowiczanie znaleźli się więc w pułapce. Trzeba było konfederację rozwiązać.

Nastąpiło to 1 października 1793 roku; ale wcześniej, już 15 września, zawiązano konfederację grodzieńską pod laską Stanisława Bielińskiego (zresztą marszałka sejmu). Jej program polityczny był „elastyczny”, a przede wszystkim nie zawierał klauzuli o konieczności zachowania całości ziem Rzeczypospolitej. Katarzyna II pochyliła się jednak z troską nad wcześniejszymi sojusznikami, zalecając ambasadorowi Jacobowi Johannowi Sieversowi podjęcie takich działań, aby sejm nie okazał targowiczanom wzgardy, bo „własny nasz honor wymaga, byśmy ludzi tak otwarcie nam przychylnych ochraniali od wszelkich zniewag i prześladowania"20. Żadnych rozliczeń zresztą w Grodnie nie planowano, choć niezadowolonych z polityki Szczęsnego, także wśród "swoich”, było wielu ${ }^{21}$.„Nowi starzy” konfederaci (układy personalne niewiele się zmieniły) zostali rok później zaliczeni do arcyzdrajców i podzielili wspólny los. Wyrazistym przykładem był marszałek nowej Rady Nieustającej Józef Ankwicz, powieszony w Warszawie 9 maja 1794 roku. Podczas pamiętnej sesji 23 IX 1793 roku, wobec jawnego już terroru i nacisków ambasadora rosyjskiego, to on właśnie zredagował specyficzną deklarację „zgody” i takiej interpretacji milczenia protestujących posłów ${ }^{22}$, która pozwalała wszystkim na zachowanie twarzy, a z drugiej strony zadowoliła Sieversa. W istocie była to zgoda na zabór przez Prusy kolejnej części terytorium Polski ${ }^{23}$. Rosyjski historyk Dmitrij Iłowajski (1832-1920) napisał:

Rzeczpospolita raz jeszcze wystąpiła na sejmie grodzieńskim ze swą sztuką krasomówczą. Utworzyła grupę opozycyjną, która przy całej swej nowski, Nakład J.K. Żupański, Poznań 1872, s. 307.

"[...] gdy przemoc dla oparcia się projektowi stoi na przeszkodzie, a cnota nań zezwolić nie dozwala, nic izbie nie pozostaje, jak okrzyknąć powszechną zgodą projekt deklaracji, a powszechnym milczeniem odpowiedzieć na proponowane przyjęcie projektu traktatowego" (Sejm grodzieński ostatni. Ustęp od 26 sierpnia do 23 września 1793, zestawił Leon Wegner, Poznań 1866, s. 209). W literackiej formie: J.I. Kraszewski Sceny sejmowe. Grodno 1793. Opowiadanie historyczne przez B. Bolesławitę, Nakładem Towarzystwa Przyjaciół Nauk w Poznaniu, Poznań 1873, s. 151. Trzeba pamiętać jednak o naciskach stosowanych wobec nielicznej, ale aktywnej opozycji na tym sejmie. Ocena jej intencji to inna sprawa.

W niezwykłej formie przedstawił to J.M. Rymkiewicz Wieszanie, s. 179-181. 
słabości dowiodła, że ubiegłe lat dwadzieścia, od czasu pierwszego podziału, nie pozbawiły ją płodów do podniesienia ducha w zamierającej już Rzeczypospolitej, chociaż to wzbudzenie jako zbyt późne nie mogło ją uratować. ${ }^{24}$

Jan Zachariasiewicz (1823-1905) pisał: „Straszliwie wspaniały był widok tego olbrzymiego konduktu, który zwłoki dziesięciowiekowej Rzeczypospolitej miał odprowadzić do grobu!..." ${ }^{25}$ Agonia trwała jednak dłużej, zatem ze złożeniem do grobu trzeba było poczekać, a wydarzenia następujące po tym sejmie, przede wszystkim zaś powstanie kościuszkowskie, chwilowo zatarły w pamięci społecznej tamten ponury obraz.

Zwracam uwagę na opowiadanie Zachariasiewicza, bo jego bohaterowie podjęli dość przewrotną próbę uzasadnienia argumentacji sejmowych „patriotów", zdecydowanie przeciwstawiających się układowi z Prusami, choć przyjęli oni wcześniej traktat rozbiorowy z Rosją, przesądzający o losach państwa. Ten wywód przeraża wręcz cynizmem politycznym, a jego konkluzja bolesną racją: „Ponieważ lud prosty woli łudzić się i szukać pocieszenia w gusłach niż poddać się niezbędnej kuracji chirurgicznej, są lekarze, którzy taką kurację zalecają - każą choremu umierać z bohaterstwem!". Ci, którzy myślą inaczej, będą mieli wszystkich przeciw sobie - opinia publiczna „obrzuci nas błotem nienawiści". Chodzi już teraz tylko o to, aby zagospodarować resztki tego, co po ojczyźnie zostało. Trzeba zatem odwagi (tak właśnie!), aby publicznie, podczas obrad, powiedzieć: „stało się! Nie mamy siły, aby rzeczy odmienić!" - i do obwieszczenia tej prawdy potrzeba bohatera... I dalej: „W sprawach publicznych jest pora, gdzie można być patriotą i nikomu ze swoich nie narazić się. Ale jest także czas, w którym prawdziwy patriota zostanie nazwany zdrajcą i odszczepieńcem... i będzie oplwan i biczowan!"26. Nie chodzi o konfrontację tej narracji z narracją historyczną, bo autor wiedział, że za tę „heroiczną" postawę „bohaterów” wynagrodzono w rublach. Chodzi raz jeszcze o podkreślenie zarówno skomplikowanych racji w wyborach politycznych, jak też skuteczności prostych technik manipulacji opinią publiczną. Nie zawsze są to sprawy łatwe do osądzenia ad hoc przez bezpośrednich świadków.

24

25

D. Iłowajski Sejm grodzieński roku 1793, s. 340.

J. Zacharjasiewicz Poseł męczennik. Obrazek z ostatniego sejmu polskiego, w: Album Muzeum Narodowego w Rapperswyl (sic!) wydane staraniem Władysława hr. Platera, Poznań 1872, s. 51.

Tamże, s. 58-61. 
Rozliczenia próbowano przeprowadzić w okresie powstania kościuszkowskiego w 1794 roku w Warszawie, po przejęciu "moskiewskich papierów”. Dokumenty te miały dać źródłową podstawę do lustracji wszystkich, którzy brali udział w zdradzie targowicko-grodzieńskiej. Ale nie wszystko zostało ujawnione, a spora część obwinianych zdążyła uciec za granicę. Stworzono jednak odpowiednie struktury, rozpoczęto też przesłuchania tych działaczy konfederacji targowickiej i uczestników sejmu grodzieńskiego, którzy pozostali w stolicy. Problemem miała zajmować się deputacja indagacyjna ${ }^{27}$. Abstrahując tu od jej powikłanych losów, błędów proceduralnych, kompetencji członków itd., zwróćmy tylko uwagę na całkowitą bezradność deputacji. Powinna ona, jako struktura polityczna, ujawnić możliwie „prostą" prawdę o postawach tej części ówczesnego społeczeństwa, która zdradziła swój kraj, współpracując z zaborcami, i ewentualnie skierować do Sądu Kryminalnego wnioski o ukaranie odpowiedzialnych. Ale tu pojawiły się problemy. Z mnóstwa pytańn ${ }^{28}$, które kierowano do przesłuchiwanych, ograniczę się do zacytowania tylko jednego, skierowanego do Fryderyka Moszyńskiego. Odegrał on istotną rolę w tworzeniu nowych zasad ustrojowych na sejmie grodzieńskim $^{29}$ :

z jakich widoków nalegałeś usilnie o rozwiązanie spisku targowickiego, podając nawet w tej mierze projekt, gdy spisek targowicki między innemi zbrodniczemi celami miał przynajmniej ten jeden dobry zamiar utrzymania całości granic, przeciwnie zaś akt grodzieński, na miejsce jego po ustąpieniu połowy kraju zawiązany, wyraźne prawie zawierał ratyfikację zaboru, tem szkodliwsze dla Ojczyzny, że była dziełem dobrowolnego aktu przez cały sejm podpisanego ? $^{30}$

Naturalnie śledczym nie chodziło o jakąś formę rehabilitacji targowicy. Radykalna i rewolucyjna próba zredukowania politycznych wyborów do wyboru

27 Na temat jej powołania i działalności: W. Tokarz Deputacja indagacyjna, PAU, Wydział Historyczno-Filozoficzny, rozprawy, seria II, tom XLII (Ogólnego zbioru t. 67) nr 2.

28 Część z tych pytań miała na celu po prostu uzyskanie przez członków deputacji jakiejkolwiek wiedzy o działaniach targowicy.

Por. np. J. Wąsicki Konfederacja targowicka i ostatni sejm Rzeczypospolitej z1793 r., s. 69 i in. O tej niezwykle ciekawej postaci: Ł. Kądziela Między zdradq a służbą Rzeczypospolitej. Fryderyk Moszyński w latach 1792-1793, Oficyna Wydawnicza Volumen, Warszawa 1993. 
między dobrem a złem okazała się zupełnie nieprzydatna. Najtrudniejsza była bowiem odpowiedź na zasadnicze pytanie: dlaczego nie reagowałeś, widząc panoszące się zło?! Dlaczego, pozostając biernym lub milcząc, je akceptowałeśsi? ? W sumie łatwiej przyszło osądzić i ukarać sprawców wieszania byłych targowiczan niż ich samych, choć to oni byli przecież odpowiedzialni za upadek państwa. W okresie tzw. pierwszej deputacji Moszyński, podobnie zresztą jak wielu innych jego kolegów, został „zrehabilitowany”... „Niesłusznie" podejrzewani o zdradę, po uzyskaniu stosownych zaświadczeń o pozytywnym wyniku lustracji, zadbali o ich natychmiastowe upublicznienie w gazetach, co rozwścieczyło reformatorów i lud Warszawy. Moszyńskiego więc przesłuchano ponownie, unieważniając wyniki wcześniejszej lustracji. Ostatecznie jednak nie zawisł na szubienicy.

Targowica stanowi część, zresztą bardzo ważną, polskiego imaginarium. Mity, jakie wokół tamtych wydarzeń były i są tworzone, nie pozwalają na racjonalną i spokojną weryfikację faktów. Czy zresztą taka weryfikacja naprawdę jest potrzebna w codziennym „użytkowaniu" historii32? Po dwóch przeszło wiekach od zdrady targowicko-grodzieńskiej funkcjonuje ona w najlepsze w przestrzeni publicznej, a nawet stanowi klucz interpretacyjny przydatny do analizy wydarzeń współczesnych ${ }^{33}$. Coraz dłuższa jest też lista „polskich zdrajców”. Wypada zgodzić się z twierdzeniem, że „przeszłość nabiera znaczenia dopiero wówczas, gdy jest przedmiotem odniesienia, jest uobecniana i reorganizowana przez współczesnośc ${ }^{34}$.

Targowica to właśnie jeden z takich „przedmiotów odniesienia”, stała się wręcz, jako się rzekło, archetypem zdrady niemal doskonałym. Spróbujmy

31 Tamże, s. 31(217).

32 To trafne określenie M. Kuli Krótki raport o użytkowaniu historii, PWN, Warszawa 2004, s. 63. Autor pisze m.in. „W polskim życiu nie tylko publicznym i w dyskursie politycznym, ale nieraz także w życiu prywatnym, historia - niezależnie od wspomnianej, niewielkiej o niej wiedzy - to zbiór spraw poważnych. Taka sytuacja istnieje od XIX wieku, poczynając od narodowych wieszczów, Kraszewskiego, Sienkiewicza, Wyspiańskiego, Matejki i Lelewela, do dziś (a w każdym razie do wczoraj). Trudno nie być w Polsce uczulonym na historię, skoro kraj karmił się nią przez długie i ciężkie okresy, a samo nawet jej kultywowanie natrafiało na przeszkody".

S. Koper Wielcy zdrajcy: od Piastów do PRL, Bellona, Warszawa 2012; W. Roszkowski Kierunek Targowica. Polska 2005-2015, Biały Kruk, Kraków 2019. Ta ostatnia pozycja jest próbą opisu współczesności. 
więc doszukać się tych elementów, które mogły przesądzić o trwałości mitu. Pierwszym z nich był zapewne język, jakim targowiczanie posługiwali się w krytyce reformatorów i przeciwników politycznych w ogóle. Rozwijali oni retorykę swoich wystąpień i aktów prawnych, dostosowując ją do zmieniających się okoliczności zewnętrznych i wewnętrznych, ale sens pozostawał ten sam - kategoryczne żądanie przywrócenia dawnego porządku, potępienie "rewolucji” i ukaranie „odpowiedzialnych” - króla i jego doradców, ale też wszystkich przedstawicieli szlachty, którzy Konstytucję zaprzysięgli. To zupełnie oczywiste. Przekaz był prosty: trzeba walczyć o wolność z uzurpatorami, którzy wprowadzili despotyzm w miejsce wolności, rząd monarchiczny w miejsce republikańskiego! Wolność, a ściślej „nasza wolność”, była istotnie najwyższą wartością, bez której nie wyobrażano sobie istnienia państwa ${ }^{35}$. Jak jednak ową „wolność" rozumieć? To był istotny problem, który rozważano w dziesiątkach, jeśli nie setkach ówczesnych publikacji. Miał on nie tylko znaczenie aksjologiczne, ale też czysto praktyczne - w jaki sposób instytucjonalnie wolność tę zabezpieczyć? Dla zwolenników reform sprawa była dość oczywista - gwarancję praw dawała konstytucja jako ustawa zasadnicza ${ }^{36}$. Dla przeciwników zaś „,wolność, polegająca przede wszystkim na osłabieniu monarchy, gwarantowała zbiór wolności szlacheckich. Bez takiej wolności Polska nie byłaby Polską" ${ }^{37}$. Targowiczanie w swoim mniemaniu walczyli o Rzeczpospolitą....

Jak trafnie zauważył Richard Butterwick, język, w jakim formułowali swoje żądania targowiczanie, nie był już językiem konfederatów barskich. Był językiem... wroga, czyli reformatorów, choć oczywiście nie wykluczało to frazeologii religijnej - Katarzyna Wielka była zawsze „narzędziem opatrzności”38. Propaganda, a przede wszystkim rzucanie „czernideł” na przeciwnika (współcześnie - „hejtowanie”) odgrywała kolosalną rolę. Historycy analizujący dzieje targowicy zwracali uwagę na prawdziwy zalew rozmaitych pism,

Por. rozważania w znakomitej analizie problemu: A. Grześkowiak-Krwawicz Regina libertas. Wolność w polskiej myśli politycznej w XVIII wieku, słowo/obraz terytoria, Gdańsk 2006, s. 326 i in.; por. również tej autorki Dyskurs polityczny Rzeczypospolitej Obojga Narodów. Pojęcia i idee, Wydawnictwo UMK, Toruń 2018.

Por. I. Małajny Z problematyki teorii konstytucji - definicja i geneza, w: Ustroje. Historia i współczesność. Polska - Europa - Ameryka Łacińska. Księga jubileuszowa dedykowana Profesorowi Jackowi Czajkowskiemu, red. M. Grzybowski, G. Kuc, P. Mikula, Wydawnictwo UJ, Kraków 2013, s. 31. 
w których deprecjonowano reformatoró $\mathrm{w}^{39}$ - w języku dla nich zrozumiałym. Ale i reformatorzy uderzali w targowiczan ${ }^{40}$. Papierowa wojna miała swoje znaczenie. Pamiętajmy, że był to okres rozwoju publicystki i generalnie wielkiego zainteresowania sprawami politycznymi, co uwidoczniło się już podczas obrad Sejmu Czteroletniego ${ }^{41}$, pilnie i na bieżąco śledzonych przez opinię publiczną. Nadawało to obradom specyficznego kolorytu i zachęcało do popisów oratorskich ${ }^{42}$.

W dobie targowicy podmiotem rozstrzygającym dla działań o charakterze perswazyjnym miała być grupa niezdecydowanych - przede wszystkim ubogiej szlachty, która po początkowym entuzjazmie dla reform zaczęła okazywać rozczarowanie. Okazała się ona trafnym adresatem propagandy w sytuacji, gdy nienawiść między stronnictwami uniemożliwiała dialog i merytoryczną polemikę. Ale do większego wysiłku zachęcała też bierność reformatorów. Krytyce ze strony targowiczan przeciwstawiano mit zgody i jedności króla z narodem, obowiązywało hasło: „wszystko pójdzie znakomicie” itd. ${ }^{43}$ Trwał ten stan do 24 lipca 1792 roku, gdy król przystąpił do targowicy. To legitymizowało konfederację, a przede wszystkim przyczyniło się do dekompozycji stronnictwa reformatorów i przyjaciół Konstytucji. Skłaniano się też do zaakceptowania "prostych" interpretacji tego, co się stało, a w sukurs temu przyszły patriotyczna literatura i gazety.

Por. K. Zienkowska Wobliczu klęski-czyli co warto ratować?, Epizod warszawsko-grodzieński, w: Trudne stulecia, s. 85 i nast.

40 Por. np. R. Kaleta Poezja antytargowicka i jakobińska, „Pamiętnik Literacki” 1950 z. 3-4:; Wiersze polityczne czasu konfederacji targowickiej i sejmu grodzieńskiego 1793 roku, opr. K. Maksimowicz, Wydawnictwo UG, Gdańsk 2008.

Por. np. A. Grześkowiak-Krwawicz Walka publicystyczna o Konstytucję 3 Maja. Maj 1791 - maj 1795, w: Sejm Czteroletni i jego tradycje, red. J. Kowecki, PWN, Warszawa 1991 s. 95 i nast. Autorka przypomina, że sama Konstytucja miała wiele cech publicystyki.

A. Danilczyk Targowica, czyli zdrada, Wydawnictwo Denart, Warszawa 2016, s. 34 i nast.

Szeroko na ten temat: J. Michalski „Wszystko pójdzie wyśmienicie”. O politycznym optymizmie po 3 maja, w: Losy Polaków w XIX-XX wieku. Studia ofiarowane Profesorowi Stefanowi Kieniewiczowi w osiemdziesiątą rocznicę jego urodzin, PWN, Warszawa 1987; K. Zienkowska W obliczu klęski czyli co warto ratować?, Epizod warszawsko-grodzieński, w: Trudne stulecia, s. 80-82: „[...] po raz pierwszy chyba w skali tak szerokiej społeczeństwo zawierzyło «naczelnikom» właśnie: królowi, sejmowym liderom i posłom wreszcie. Zawierzyło czynom, które zrealizowały się w Konstytucji 3 maja i innych reformach, i zawierzyło słowom. Słowom o moralnym odrodzeniu, niepodległości zjednoczonego pod królewskim berłem narodu i państwowej suwerenności. O przychylności i podziwie bliżej nie zdefiniowanej Europy, o dodatniej konotacji, jaką od tej pory cieszyć się będzie imię Polska". 
Spojrzeć też wypada na inne czynniki, które sprzyjały zachowaniu owych wydarzeń w pamięci społecznej. Rzecz, jak się wydaje, przede wszystkim w metodach politycznego działania targowiczan. Tworzyły one kontekst wydarzeń, ale również wprowadzały do nich nową jakość. Po pierwsze, wszystkie oceny sytuacji czy opinie formułowane przez kierownictwo targowicy i sporządzane na użytek chwili były starannie analizowane przez dyplomatów, generałów i urzędników rosyjskich w Petersburgu. Organizacja procesu decyzyjnego, którą zresztą precyzyjnie przedstawili już Dimitrij Iłowajski i Władysław Smoleński, potwierdziły ustalenia późniejszych historyków. Ukazuje się tryb działania politycznego zupełnie nieznany dotąd polskim elitom. Ostateczne decyzje podejmowała zawsze Katarzyna II, komunikując się z targowiczanami wyłącznie za pośrednictwem swoich urzędników - generałów i ambasadora. Nie była to zupełna nowość, bo od 1776 roku funkcjonowało, jak to określił Emanuel Rostworowski, „kondominium królewsko-ambasadorskie", ale po zerwaniu tej współpracy Stanisława Augusta zastąpiła konfederacja targowicka. Okazało się, że powstała w ten sposób bardzo skuteczna forma zarządzania ruchem politycznym. Za ewentualne niepowodzenia karano lub surowo upominano urzędników, ale odpowiedzialność, i to nie tylko w sensie politycznym, ponosili również przywódcy ruchu - groziły im surowe sankcje z konfiskatą dóbr prywatnych na czele. Była to jednak tylko teoria, bo w praktyce ambasadorzy rosyjscy korzystali raczej z innych form nacisku, równie skutecznych co „tańszych”: gróźb, perswazji i korupcji ${ }^{44}$. Koniec końców wszyscy, z królem na czele, siedzieli w kieszeni rosyjskiego ambasadora. Od czasu do czasu niektóre decyzje Rosja konsultowała z sojusznikami - Prusami i Austrią, które tych nowych metod dopiero się uczyły. Nie było to proste, bo po zdradzie Prus w dobie Sejmu Wielkiego tamtejsi dyplomaci znajdowali się w trudnej sytuacji. Wśród szlachty dominowała nieufność i wrogość wobec dawnego lennika. Stronnictwo pruskie w Grodnie było słabe i koniec końców „pomocy” musiał mu użyczyć Sievers.

Po drugie, opozycja sięgnęła po wypróbowany środek walki o swoje cele konfederację generalną. Wygodny i skuteczny, bo zasady jej działania kształtowały zwyczaj, tradycja i często osobowości liderów. W XVIII wieku, który bywa nazywany „wiekiem konfederacji”, stanowiły one najważniejszą formę realizacji celów politycznych szlacheckiego suwerena, organizującego się

44 Por. R. Butterwick Oświecona monarchia Stanisława Augusta Poniatowskiego (1764-1795), w: Rozkwit i upadek I Rzeczypospolitej, red. R. Butterwick, przeł. D. Kuczyńska-Szymala, Bellona, Warszawa 2001, s. 259. 
w związek opowiadający się za władzą króla lub przeciwko niej ${ }^{45}$. Ale też, zgodnie z doktryną, konfederacje jako instytucje stanu wyjątkowego miały służyć wprowadzeniu i utrzymaniu porządku w państwie ${ }^{46}$. Sejmy w czasach Stanisława Augusta Poniatowskiego przeważnie były skonfederowane (na 14 sejmów ogółem skonfederowanych było aż 9), co umożliwiało im przyjmowanie uchwał bez sprzeciwu - liberum veto traciło powoli rację bytu, skutecznie też eliminowano opozycję $e^{47}$. O tym jednak, czy sejm może odbywać się pod węzłem konfederacji, decydowała Rosja - od 1768 roku gwarantka zasad ustrojowych.

Natomiast konfederacje generalne, takie jak interesująca nas targowicka, powinny być, zgodnie z tradycją, tworzone „od dołu”; od rozwiązania konfederacji barskiej w 1772 roku aż do targowicy konfederacji generalnych zresztą nie zwoływano. Tymczasem w przypadku konfederacji targowickiej było odwrotnie - wspomniana grupa ogłosiła się Generalnością, wybrała na marszałka Szczęsnego Potockiego, a następnie, korzystając z "pomocy” wojsk rosyjskich, rozpoczęła budowę struktur w terenie. Należało teraz pozyskać szlachtę, bo bez niej nie mógł funkcjonować żaden system władzy, a tym bardziej odwołujący się do republikańskich praw Rzeczypospolitej. Dynamikę tego procesu w Koronie przeanalizował wnikliwie Dariusz Rolnik. Poparcie dla targowicy wzrastało stopniowo. Jesienią 1792 roku konfederacje zostały zawiązane już we wszystkich województwach - wybrano też 557 konsyliarzy ${ }^{48}$. Nie ulega wątpliwości, że szlachta obawiała się sekwestracji dóbr przez wojska rosyjskie, stacjonujące niemal wszędzie. Na Litwie bracia

45 Por. np. J. Porazinski „Rzeczpospolita porzqdna”. Konfederacje generalne czasów Augusta II jako alternatywa anarchii wewnętrznej?, w: Rzeczpospolita wXVI-XVIII wieku. Państwo czy wspólnota?, red. B. Dybaś, P. Hanczewski, T. Kempa, Wydawnictwo UMK, Toruń 2007, s. 67-81.

46 J.A. Gierowski Konfederacje a postawa polityczna szlachty, w: Dzieje kultury politycznej w Polsce, red. J. Gierowski, PWN, Warszawa 1977.

47 Na temat sejmów skonfederowanych: W. Stanek Konfederacje generalne, s. 185 i in.; tegoż, Konfederacja sejmowa z 1776 roku - narzędzie dworskiego zamachu stanu, "Acta Universitatis Nicolai Copernici. Historia XXVIII - Nauki Humanistyczno-Społeczne" 1983 Z. 259, s. 125 i nast. Zdaniem autora król wyciągnął wnioski z istniejącej od 1764 roku i utwierdzonej na sejmie delegacyjnym w 1768 roku zasady mówiącej, „iż działalność prawodawcza sejmów wolnych ograniczona została do drugorzędnych kwestii ekonomicznych, zaś materie stanu (a więc wszelkie reformy systemu politycznego) zachowano dla sejmów skonfederowanych uzależnionych od zgody rosyjskiego protektora".

48 D. Rolnik Szlachta koronna wobec konfederacji targowickiej (maj 1792 - styczeń 1793), Wydawnictwo UŚ, Katowice 2000, s. 122 i nast. 
Kossakowscy - Szymon w randze rosyjskiego generała lejtnanta i Józef Kazimierz, biskup inflancki - bez skrupułów stosowali terror i przemoc, wykorzystując rosyjskich sojuszników ${ }^{49}$. Kossakowscy działali w imię własnego interesu - Szymon mianował sam siebie hetmanem wielkim litewskim, a Józef został zarządcą dóbr biskupa krakowskiego. W Koronie takich przypadków nadużyć i terroru raczej nie było. Nie próbowali też targowiczanie wykorzystywać innych instrumentów nacisku, na przykład podporządkowanych sobie sądów. Motywy zmiany orientacji politycznej przez szlachtę były więc różne. Część skłonna była po prostu ułożyć sobie jakoś życie, inni prawdopodobnie zamierzali „oszukać" konfederację, tylko pozornie udzielając jej poparcia, aby w przyszłości ją zniszczyć... Coś jakby wallenrodyzm? Mimo całej pogardy okazywanej Szczęsnemu Potockiemu długo nie dostrzegano alternatywy. Należy przypuszczać, że to upokorzenie trwale zapadło w pamięć i tego, i kolejnych pokoleń. Z drugiej strony idea konfederacji jako formy organizacyjnej przetrwała i miała wpływ na tworzenie struktur podejmujących walkę z obcą przemocą.

Po trzecie, jaki wpływ na trwałość mitu o zdradzie miał fakt, że opozycja antykrólewska zwróciła się o pomoc do Rosji, choć było to zaprzeczenie tradycji konfederacji barskiej - pierwszego, jak twierdzą niektórzy historycy, antyrosyjskiego powstania? Takie pytanie mogło zrodzić się tylko w głowach historyków i publicystów w XIX i XX wieku. W XVIII wieku sprawa była stosunkowo prosta. Odwoływanie się do pomocy Rosji w rozstrzyganiu wewnętrznych dylematów Rzeczypospolitej Obojga Narodów nie było niczym nadzwyczajnym. W dobie wielkiej wojny północnej (1700-1720) car Piotr I był sojusznikiem króla polskiego Augusta II oraz wspierającej go konfederacji sandomierskiej. Można powiedzieć, że od 1704 roku, kiedy między konfederacją a Rosją został podpisany układ narewski, a na teren kraju po raz pierwszy w roli sojusznika wkroczyły wojska rosyjskie, które miały wspomóc Rzeczpospolitą w walce ze Szwedami i antykrólem Leszczyńskim, car stał się w zasadzie protektorem porządku politycznego. I tę rolę akceptowano. Tak było na Sejmie Niemym, który zakończył antysaską i antykrólewską konfederację tarnogrodzką (1715-1717). Wbrew uproszczonym opiniom posłowie na tym sejmie zachowali jednak milczenie nie dlatego, że sterroryzowały ich

49 Tamże, s. 42 i in.; K. Michaluk Upadek u szczytu kariery. Ostatnie lata Józefa Kazimierza Kossakowskiego (1792-1794), "Zeszyty Naukowe. Zbliżenia Cywilizacyjne” 2017 t. XIII nr 2, s. 45: Autor formułuje ciekawą opinię na temat swego bohatera: „Był zdrajcą w równym stopniu, jak przez pisarstwo i system wartości był oświeconym sarmatą". 
wojska rosyjskie, ale dlatego że zgromadzenie to przyjęło wynegocjowany wcześniej i przedstawiony do akceptacji przez posłów tzw. traktat warszawski (3 XI 1716 r.), który zawierał warunki porozumienia z królem i szlachtą oraz reformy wewnętrzne. Jak obliczył Robert Kołodziej, negocjacje trwały aż 129 dni, a więc mniej więcej tyle, ile potrzebowałby na ich przedyskutowanie i przyjęcie sejm „zwyczajny" ${ }^{50}$. Ucieranie porozumienia trwało długo, bo uczestniczyli w tych rokowaniach dyplomaci carscy, ale do uznania pozycji cara za protektora lub gwaranta ustroju nie doszło. Po Sejmie Niemym obecność Rosji w polityce Rzeczypospolitej była już czynnikiem stałym, a „stronnictwa reformatorskie", najczęściej związane z polskim dworem królewskim, zawsze musiały liczyć się ze zdaniem Petersburga, który miał niczym nie ograniczone pole działania. Korzystne dla Rosji rozstrzygnięcie problemu bałtyckiego zapewniło jej hegemonię w tej części świata, ale też awans do „wspólnoty narodów obyczajnych"51. Zarówno August III Sas, jak i Stanisław August Poniatowski zawdzięczali swoje korony rosyjskiej interwencji.

Zerwanie przez stronnictwo reformatorskie podczas Sejmu Wielkiego z kursem prorosyjskim i zwrot w kierunku Prus, które „poparły” polskie reformy, podpisując 29 III 1790 roku odpowiedni traktat sojuszniczy ${ }^{52}$, wydawało się posunięciem dobrze skalkulowanym. Opozycja natychmiast zajęła „zwolnione" przez „patriotów” miejsce w kolejce do łask carycy, choć nie miała żadnych atutów ani potencjału. Katarzyna II stanowiła dla opozycyjnych magnatów instancję odwoławczą jako gwarantka polskich wolności, ponieważ, odrzuciwszy ustawodawstwo Sejmu Wielkiego i Konstytucję 3 maja, nie uznawali oni także zerwania przez ten sejm rosyjskich gwarancji. Targowiczanie byli więc, uwzględniając tę perspektywę, „przy prawie”.

To czynniki, które wykorzystała konfederacja (a więc: umiejętny dobór argumentów i sprawna propaganda wymierzona w stronnictwo reformatorskie, ścisłe powiązanie celów politycznych z celami Rosji i niezwykłe wręcz posłuszeństwo wobec dyspozycji Katarzyny II oraz jej generałów, wreszcie

50 R. Kołodziej Sejm Niemy na tle praktyki funkcjonowania staropolskiego parlamentaryzmu, w: Sejm Niemy. Między mitem a reforma państwa, red. M. Zwierzykowski, Wydawnictwo Sejmowe, Warszawa 2019, S. 137-176.

51 K. Zernack Polska i Rosja. Dwie drogi w dziejach Europy, przeł. A. Kopacki, Wiedza Powszechna, Warszawa 2000 s. 283 i nast.

52 Por. np. A. Pufelska Der bessere Nachbar? Das politische Preussenbild zwischen Politikund Kulturtransfer (1765-1795), De Gruyter, Oldenburg 2017, s. 258 i nast.; Z. Anusik Rzeczpospolita wobec Rosji w ostatniej fazie obrad Sejmu Wielkiego (1791-1792), "Przegląd Nauk Historycznych” 2017 r. $\mathrm{XVI}$ nr 2, s. 75 inast. 
wykorzystanie możliwości organizacyjnych, jakie zawsze dawała działaczom politycznym konfederacja), zaważyły w pierwszej kolejności na „sukcesie” targowicy. Na jej upadku zresztą również. Już wówczas, czyli w końcówce XVIII wieku, pojawiło się wiele analiz targowicy pisanych przez uczestników wydarzeń. Do najciekawszych zaliczyłbym słynną Biblię targowicką. Księgi Szczęsnowe pióra Juliana Ursyna Niemcewicza ${ }^{53}$. Nie tylko ze względu na oryginalną formę - jest to pamflet polityczny i trawestacja Bibliij ${ }^{54}$ - ale przede wszystkim na interesującą dla historyka analizę postaw „hersztów targowickich” i świata dawnej Rzeczypospolitej, który próbowali odbudowaćlub może raczej wskrzesić. Szczęsny Potocki jako kreator tego świata rozpoczął od destrukcji tego, co istniało, i z „niczego" stworzył naród, „bez części całość”, a siebie nazwał "związkiem”. Osiągnął idealny chaos i zamęt, którymi teraz mógł sam zarządzać, wywracając wszystko na nice. Wolność, równość, niepodległość te wartości rozumiane na wspak miały podnieść „znaczenie i powagę kraju” oraz zapewnić „szczęście Polski”. Naród i jego przedstawiciele powinni słuchać i wielbić Szczęsnego w „pokorze i głupstwie”, bo wcześniej zostali pozbawieni edukacji... Lektura tego tekstu nawet dziś nie należy do przyjemnych, bo to nie tylko krytyka ściśle określonych działaczy politycznych, ale też wytknięcie Polakom ich wad narodowych. A jednak trzeba przyznać, że Księgi Szczęsno$w e^{55}$, jeśli czytamy je ze świadomością, jaki był koniec tej historii, a nie miał jej przecież wówczas jeszcze Niemcewicz, to znakomity przewodnik dla tych, którzy pragną przyjrzeć się agonii Rzeczypospolitej w XVIII wieku.

To, że targowica jako mit funkcjonuje do dziś, pomimo innych doświadczeń tego rodzaju, wynika prawdopodobnie z jej specyficznej „doskonałości”. Autorka cytowanej wyżej książki o problemie polskiej zdrady stwierdziła w jednym z wywiadów:

Zdradę rozumiemy intuicyjnie jako nadużycie zaufania, moment, kiedy ktoś z „naszych” przechodzi na stronę „obcych”, sprzeniewierzając się

53 Fragment Biblii Targowickiej. Księgi Szczęsnowe, przedruk wiedeńskiej edycji z 1793 r., Kraków 1895.

Por. J. Nowak-Dłużewski Satyra polityczna konfederacji targowickiej i sejmu grodzieńskiego, Kraków 1935 , s. 52 i nast. blii, biskup Józef Kossakowski, ale wydaje się, że w zaistniałej sytuacji szukał on raczej „innej drogi" odzyskania poparcia szlachty; por. M. Kuźma Ewangelia, polityka i karnawał. O „Kontynuacji Biblii Targowickiej lózefa Kossakowskiego", „Napis”2007, seria XIII, s. 249-271. 
wartościom, które wyznajemy [...] dyskurs zdrady to zdrada przypisana, bardzo często niemająca nic wspólnego z rzeczywistością. [...] Dyskurs zdrady ma kilka funkcji: perswazyjną, prewencyjną i piętnującą. Chodzi o to, aby pokazać, kto ma realną władzę i kontrolę nad wspólnotą, kto wyznacza centralne dla niej wartości i idee oraz zakreśla jej granice ${ }^{56}$.

Historyk powinien zapytać tu jeszcze o genezę owej „realnej władzy”, jej cele i organizację.

\section{Abstract}

\section{Jarosław Porazinski}

NICOLAUS COPERNICUS UNIVERSITY (TORUŃ)

Targowica: The Defence of the Commonwealth

Porazinski examines the Targowica Confederation of 1792-93 to shed light on the myth of national treason that continues to mark Polish literature as well as journalism. Elements that help consolidate this myth and that support its manifold applications include the efficient communication of the Confederation's objectives, close ties between these objectives and Russia's policy and administration, as well as the fact that as a form of organising the landed gentry the general confederation offered opportunities for action that were readily seized. By alluding to these themes some Polish literary writers and journalists produce associations that their readers find easy to accept.

\section{Keywords}

Targowica Confederation, Great Sejm 1788-1792, Grodno Sejm 1793, gentle revolution, targowiczanin, supporter of the Targowica Confederation, political literature, the Constitution of 3 May 1791

56 Gry w zdradę. Rozmowa o książce „Hańba! Opowieści o polskiej zdradzie” z Agnieszką Haską rozmawia KrzysztofSztafa, „Kultura Liberalna” 2018 nr 492. 